\title{
Role of planting depth and mulching on growth and yield components of autumn potato crop sown at different dates
}

\author{
Mohammad Ilyas* and Gohar Ayub \\ Department of Horticulture, The University of Agriculture Peshawar Pakistan \\ *Corresponding author's email: ilyas_swati88@yahoo.com \\ Citation \\ Mohammad Ilyas and Gohar Ayub. Role of planting depth and mulching on growth and yield components of \\ autumn potato crop sown at different dates. Pure and Applied Biology. Vol. 6, Issue 4, pp1436-1449. \\ http://dx.doi.org/10.19045/bspab.2017.600155
}

Received: 17/08/2017 Revised: 08/11/2017 Accepted: 18/11/2017

Online First: 30/11/2017

\section{Abstract}

Field experiments were carried out to study the role of various planting depths i.e. 10, 15 and 20 $\mathrm{cm}$ along with mulching on growth and yield attributes of autumn potato crop sown at different dates (October- 01, 15 and 29) at Horticulture Research Farm, The University of Agriculture Peshawar, during 2014-15 and 2015-16. The experiment was laid out in Randomized Complete Block Design (RCBD) with split plot arrangement. Sowing dates were kept in main plot, while planting depth and mulching were in sub plot. The two years average results revealed that sowing dates, planting depth, mulch treatments and their interactions have significant effects on potato growth and yield parameters. Potato crop sown earlier on October 01 showed maximum plant height $(50.4 \mathrm{~cm})$, number of leaves plant ${ }^{-1}(33)$ and marketable tuber yield $\left(16.2 \mathrm{t} \mathrm{ha}^{-1}\right)$. Regarding planting depths, tuber planted at a depth of $15 \mathrm{~cm}$ produced maximum emergence (86\%), plant height $(45.5 \mathrm{~cm})$, number of leaves plant ${ }^{-1}(32)$ and marketable tuber yield $\left(13.8 \mathrm{t} \mathrm{ha}^{-1}\right)$ as compared to tubers planted at a depth of 10 and $20 \mathrm{~cm}$. Mulching resulted in maximum emergence (83\%), plant height $(42.6 \mathrm{~cm})$, number of leaves plant ${ }^{-1}(30)$ and marketable tuber yield $\left(13.6 \mathrm{t} \mathrm{ha}^{-1}\right)$ as compared to no mulching. The interaction effect of sowing dates, planting depth and mulching significantly affected all the growth and yield parameters. Therefore, it can be concluded from the results that early sowing of potato crop on October 01 at a depth of $15 \mathrm{~cm}$ with organic mulching resulted in better growth and yield of autumn potato crop under the climatic condition of Peshawar, Khyber Pakhtunkhwa, Pakistan.

Keywords: Potato; Sowing dates; Planting depth; Mulching

\section{Introduction}

Potato (Solanum tuberosum L.) a member of the nightshade family (Solanaceae) is a main world food crop produced and consumed worldwide. It is ranked fourth place among the most important food crops, after wheat, rice and maize [1]. The potato crop is sensitive to heat, cold, and drought; consequently, climate change is projected to have a large, and in many cases, negative impact on yields in many potato growing regions. Heat stress is a serious threat for potato production. Elevated temperatures accelerate leaf senescence and double respiration rates for each $10{ }^{\circ} \mathrm{C}$ increase, resulting in a negative carbon balance on hot days [2]. Tuber initiation is restricted in most genotypes, when night temperatures 
exceed $17^{0} \mathrm{C}[3]$ and the optimal temperature for tuber bulking ranges between $14{ }^{0} \mathrm{C}$ and $22{ }^{0} \mathrm{C}$. Higher temperatures decrease tuber growth [4] and can cause misshapen or chain tubers, high sugar levels, low starch contents, and glycoalkaloid accumulation [5]. Under hot and dry conditions, high vapor pressure deficit increases transpiration and insufficient water supply causes drought stress, resulting in yield losses.

Soil mulching with organic material is one method of soil water conservation and also helps in maintaining a constant soil temperature within the crops root system [6]; [7]. Mulch is very important for plants, because it maintain proper moisture by reducing daily temperature fluctuations, and also reduce soil warming in summer months, thus making better soil condition for plant growth and development [8]. Temperature stress that occurs at high soil temperature at uncovered soil $\left(32-34{ }^{\circ} \mathrm{C}\right)$, may be minimized by the use of the mulch [9]. A variety of types of mulch leads to an increase in soil moisture content as a result of decreased evaporation from the soil surface compared to that of un-mulched soil [10].

The effects of planting depth on potato growth and development have been investigated by many scientists [11, 12]. Rapid sprout emergence from deeper planted seed tubers or seed pieces have been reported. It has been observed that soil moisture is the limiting factor for sprout emergence at shallow planting depths [11]. Conversely [12], indicated shallow planting hastened plant emergence. [13] found soils at $5.1 \mathrm{~cm}$, on average, had warmer soil temperatures following planting than those at $10.2 \mathrm{~cm}$. Warmer soil temperatures had a positive influence on sprout growth when moisture level was adequate throughout the profile. The relationship between tuber greening, planting depth and tuber position within the hill have been studied [12]. These studies report that as mother tubers or seed pieces are planted closer to the soil surface, daughter tubers typically grow closer to the soil surface. Tubers closer to the soil surface are more likely to become green, sunburn [14], or infected with phytophthora infestans as the season progresses [15]. Therefore, this study was conducted to find out the role of different sowing dates, planting depth and mulching treatments on growth and yield of autumn potato crop.

\section{Materials and methods}

The experiment entitled "Role of planting depth and mulching on yield and quality components of autumn potato crop sown on different dates" was carried out at Horticulture Research Farm, The University of Agriculture Peshawar during the autumn growing season of the years 2014-15 and repeated in 2015-16. Prior to the sowing of potato crop in each year, five soil samples from different sites of the experimental block, were taken with the help of an auger at 0-15 cm depth. Different soil physicochemical characteristics were analyzed.

The land was well prepared through twice plough two weeks before the planting during both the years. The ridges were prepared manually $70 \mathrm{~cm}$ apart. Sound and healthy seed tubers harvested from the last autumn crops were used. Tubers of the available variety Kuroda packed in bags. More or less uniform whole seed tubes of about 20 - 30g in weight were used for planting. Seed potatoes were planted in each unit plot maintaining a spacing of $70 \mathrm{~cm} \times 25 \mathrm{~cm}$. Both organic and in-organic fertilizers were applied to the experimental field. Well-rotten Farm Yard Manure (FYM) was applied @ 25 $\mathrm{t} \mathrm{ha}^{-1}$ just after the soil was ploughed with tiller 15 days before planting. While chemical fertilizers were applied @ 120:100:80 NPK $\mathrm{kg} \mathrm{ha}^{-1}$ in the form of Urea, Di ammonium phosphate (DAP), and Potassium Sulphate.

\section{Experimental design and layout}

The experiment was laid out in Randomized Complete Block Design (RCBD) with split 
plot arrangement having four replications. Date of sowing was kept in main plots, while planting depth and mulch treatments were allotted to sub plots. The size of each main plot was $10.92 \mathrm{~m}^{2}$, while that of each sub-plot (experimental unit) was $1.30 \mathrm{x} 1.40 \mathrm{~m}^{2}$. There were 2 rows of potato plants in each sub-plot, each row $1.30 \mathrm{~m}$ long and spaced $0.70 \mathrm{~m}$ apart. Treatments details were as under (Table 1).

Table 1. Treatments details

\begin{tabular}{|c|l|l|}
\hline $\begin{array}{l}\text { Factor A. } \\
\text { Sowing Dates (SD) (Main plot } \\
\text { factor) }\end{array}$ & $\begin{array}{l}\text { Factor B. } \\
\text { Planting Depth (PD) (Sub plot } \\
\text { factor) }\end{array}$ & $\begin{array}{l}\text { Factor C. } \\
\text { Mulching (M) (Sub } \\
\text { plot factor) }\end{array}$ \\
\hline October 01 & $10 \mathrm{~cm}$ & Control \\
\hline October 15 & $15 \mathrm{~cm}$ & Mulching \\
\hline October 29 & $20 \mathrm{~cm}$ & \\
\hline
\end{tabular}

Data was recorded on emergence $\%$, plant height $(\mathrm{cm})$, number of leaves plant ${ }^{-1}$ and marketable yield $\mathrm{t} \mathrm{ha}^{-1}$

\section{Results and discussion Emergence (\%)}

Data concerning emergence $(\%)$ of tubers in response to different sowing dates (SD), planting depth (PD) and mulching (M) is shown in Table 2. Emergence (\%) was significantly affected by planting depths, mulching and year as source of variation, while there was no significant effect of sowing dates on emergence (\%). The interactions were not significant except SD $\mathrm{x}$ $\mathrm{M}$ and PD x $\mathrm{M}$ interactions (Figure $1 \& 2$ ). The emergence $(86 \%)$ was highest; where tubers were sown at $15 \mathrm{~cm}$ depth, while lowest $(72 \%)$ at $20 \mathrm{~cm}$ depth. Mulching significantly increased emergence $(83 \%)$ as compared to $(75 \%)$ in control. The mean data showed that emergence in $2015(80 \%)$ was higher than that in 2014 (77 \%). The interaction effect of SD $\mathrm{x}$ M showed that mulching have more emergence than no mulching irrespective of sowing date as compared to no mulching. In case of no mulching emergence was depressed, when the crop was sown on October 15 (Figure 1). The PD $\mathrm{x} M$ interaction as presented in (Figure 2) indicated that mulching was effective, when sowing depth was increased from 10-15 cm, while emergence linearly decreased with increased in depth of seed sowing. Mulching is recommended when tubers are planted at depth of $10-15 \mathrm{~cm}$ only. Planting depth and mulching has an effect on emergence. Tuber planted at a depth of $15 \mathrm{~cm}$ resulted in maximum emergence $(\%)$. The increase in emergence $(\%)$ at $15 \mathrm{~cm}$ depth could be due to optimum temperature, soil moisture at sowing time. Soil temperature, water supply and soil fertility regulate the sprouting behavior of tubers [16]. As shallow planting results in increase surface temperature and moisture stress, which affect tuber emergence. Also in case of deep planting failure of emergence can occurs as potato sprouts had to come across a long distance of the ground to emerge. The results are in agreement with those of [17], who reported that each potato cultivar has its own accumulated heat units for eye and sprout development and if there is enough moisture available maximum emergence will occur. Lack of available water will influence the water uptake by the seed tuber [18], which is needed for physiological processes and act as a medium for biochemical reactions in seed tuber [19], such as the transportation of soluble sugar into the growing bud. [20] reported that percentage of plant emergence was affected by planting depth; seed tuber placed deeper resulted in lowering the plant emergence. Also planting seed tubers too shallow, can lead to tuber greening and 
moisture stress due to soil surface heat and evaporation [21].The rate of sprout growth increased as soil temperature increased from 10 to $20{ }^{0} \mathrm{C}$. Soil temperature below $10{ }^{0} \mathrm{C}$ delay and reduce sprout growth [22]. Soil temperature above $25{ }^{0} \mathrm{C}$ also delay emergence [23]. The increase in emergence $\%$ due to mulching may be related to providing optimum conditions of temperature, moisture. Straw mulch decreased the maximum soil temperature, increased the minimum soil temperature and decreased the soil temperature at day time and night which has a positive effect on emergence [24]. The soil temperature at the mulching treatments was higher than the control in winter, but in spring it can decreased the soil temperature. [25] reported that mulching significantly increased emergence rate of yam by $46 \%$ than the un mulched. Increased emergence and more rapid development of setts in mulched yams could be attributed to an increase in soil moisture content and the consequent modification of soil temperature under mulched plot [26].The increased in emergence $\%$ in 2015 could be due to the prevailing favorable weather condition because of higher precipitation and optimum temperature in 2015. The increased soil moisture content played an important role in dissolving nutrients and absorption [27], which in turn positively affected the emergence \%. Temperature, water supply during growth and storage are important environmental factors that regulate the sprouting behavior [28]. Sprout growth rate decreases with decreasing soil water potential and this effect is greater at high temperature than at low temperature [22]. Seed tubers require sufficient moisture to support sprouts until emergence [29]. Temperature and moisture significantly affected sprout growth rate, assessed as the sprouting capacity of the tubers. Sprouting capacity of seed tubers increased with increasing temperature and water potential [30].

Table 2. Emergence \% as affected by sowing dates, planting depth and mulching

\begin{tabular}{|l|l|l|l|}
\hline \multicolumn{2}{|c|}{ Years } \\
\hline Sowing dates (SD) & $\mathbf{2 0 1 4}$ & $\mathbf{2 0 1 5}$ & Mean \\
\hline October 01 & 77 & 81 & 79 \\
\hline October 15 & 77 & 79 & 78 \\
\hline October 29 & 78 & 81 & 79 \\
\hline LSD $(0.05)$ & & & NS \\
\hline Planting Depth (cm) (PD) & 78 & 80 & \\
\hline 10 & 84 & 87 & $79 \mathrm{~b}$ \\
\hline 15 & 71 & 73 & 86 a \\
\hline 20 & & & $72 \mathrm{c}$ \\
\hline LSD $(0.05)$ & & & 1.34 \\
\hline Mulching (M) & 74 & 76 & \\
\hline Control & 81 & 85 & $75 \mathrm{~b}$ \\
\hline Mulching & & & 83 a \\
\hline Significance & $77 b$ & $80 \mathrm{a}$ & $* *$ \\
\hline Year & Sig Level & Interactions & Sig Level \\
\hline Interactions & ns & SD x PD x M & ns \\
\hline SD x PD & & & \\
\hline
\end{tabular}




\begin{tabular}{|c|c|c|c|}
\hline $\mathrm{SD} \times \mathrm{M}$ & $* *$ & $Y \times S D \times P D$ & ns \\
\hline $\mathrm{PD} \times \mathrm{M}$ & $* *$ & $Y \times S D \times M$ & ns \\
\hline$Y \times S D$ & ns & $Y \times P D \times M$ & ns \\
\hline$Y \times P D$ & ns & $Y \times S D \times P D \times M$ & ns \\
\hline$Y \times M$ & ns & & \\
\hline
\end{tabular}

Means not followed by the same letters are significantly different.

*, ** show probability level of 5 and $1 \%$, correspondingly.

ns means non-significant

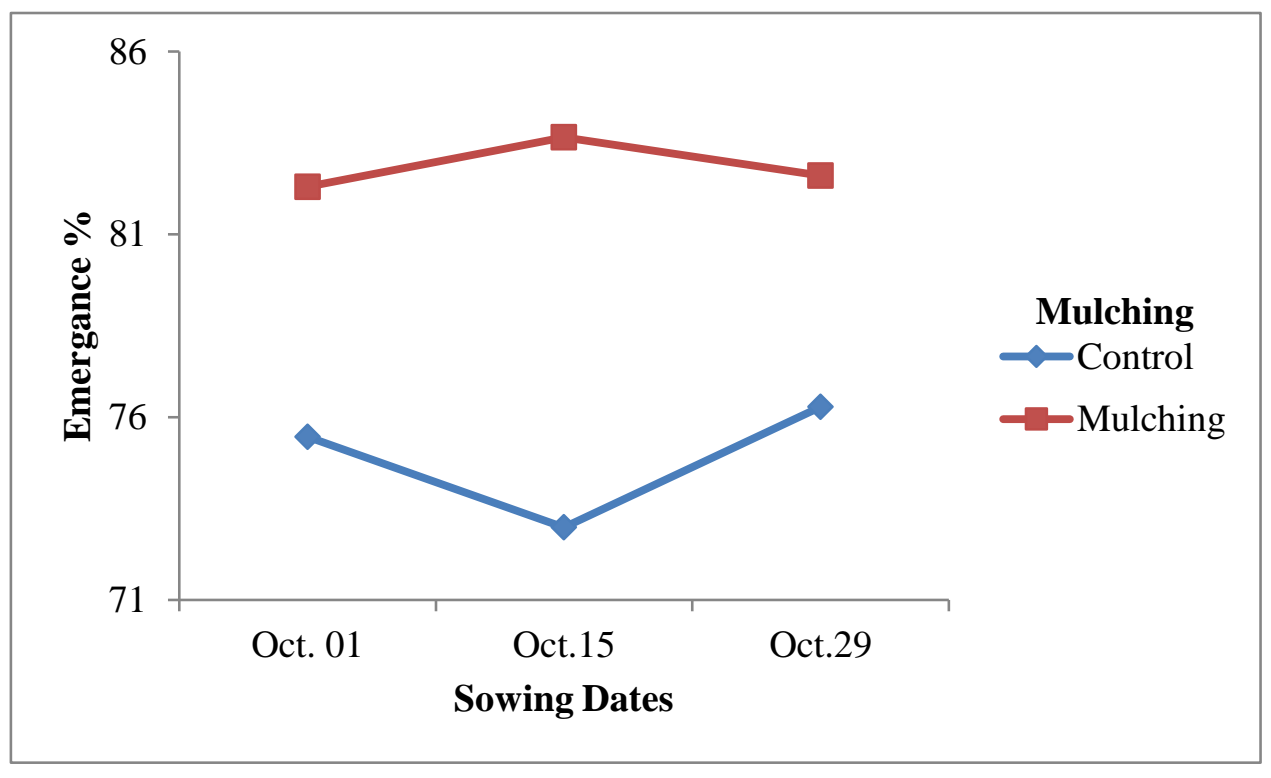

Figure 1. Emergence \% of tubers as affected by different sowing dates and mulching

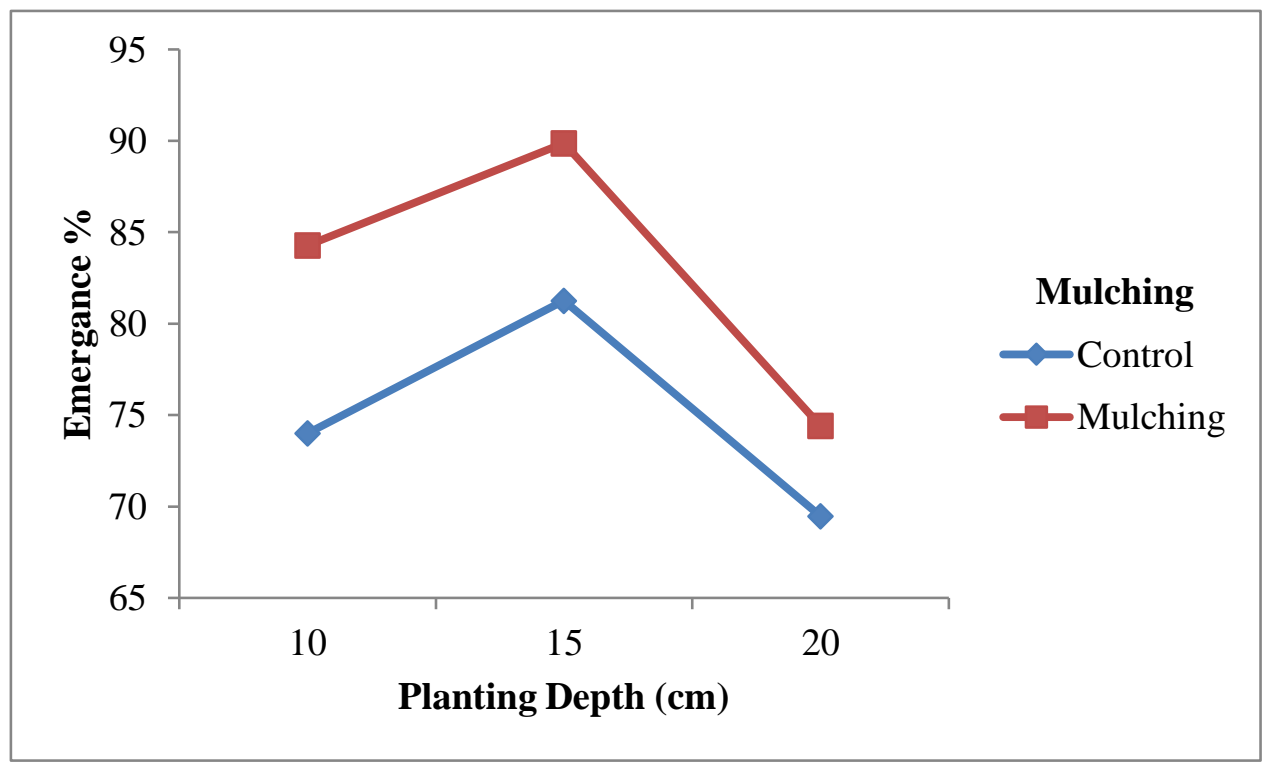

Figure 2. Emergence \% of tubers as affected by different planting depth and mulching Plant height $(\mathbf{c m})$ 
It is evident from the data in table 3 regarding plant height that there was significant variation between different sowing dates, planting depth and mulching treatments. The SD $x$ PD interaction remained significant, while rest of the interactions were not significant. Sowing potato on October 01 resulted in significantly tallest plants $(50.4$ $\mathrm{cm})$ as compared to sowing on October 15 $(44.2 \mathrm{~cm})$ and October $29(29.4 \mathrm{~cm})$. As for as planting depth is concerned, highest plant height $(45.5 \mathrm{~cm})$ was noted at a depth of 15 $\mathrm{cm}$, whereas lowest plant height $(37.4 \mathrm{~cm})$ was recorded in deep planted i.e. $20 \mathrm{~cm}$ plants. Regarding the mulching effect, maximum plant height $(42.6 \mathrm{~cm})$ was noted in mulching as compared to $(40.0 \mathrm{~cm})$ in control. Figure 3 showed the SD $x$ PD interaction, which revealed that early planting seems to have promoted plant height and plant achieved maximum height with October 01 at $15 \mathrm{~cm}$ depth.

Early planting resulted in tallest plant as during this stage, air temperature was maximum as compared to rest of the sowing dates. [31], reported that plant height or stem length is simply the sum of the lengths of each of the internodes. Stem elongation depends on internodes number or internodes length or both. Internodes length in many plants is greatly influenced by diurnal temperature fluctuations. Internodes length increased with increasing average temperature and increasing day-night temperature fluctuations, except at low day temperature $\left(15^{\circ} \mathrm{C}\right)$, where there was little response to day night temperature fluctuation. [32] reported that supra-optimal temperature resulted in taller plants for potato. [33] stated that at high temperature (night temperature above $20{ }^{\circ} \mathrm{C}$ and day temperature above $30{ }^{\circ} \mathrm{C}$ ), stems are taller because the internodes are longer.

Planting depth also has a significant effect on plant height. As the planting depth increased, the stem length and so plant height decreased. The decrease in stem length with increase in planting depth could be, because at shallow planting the plants emerged fast and had more growth period. Also at lower planting depth, the difference in the exposed stem could have contributed positively to stem length, while the buried stem for higher planting depth contributed negatively to stem length. This could also be attributed to light availability as it has been reported that increase of steam number will lead to increase of bush height due to light availability and its effect on increase of length number of node. [34], also reported decrease in plant height of potato with increase in planting depth.

Straw mulch acts as a source of organic matter. The increase in plant height [35] with mulching might be due to the decomposition of organic matter, with the subsequent releases of available nutrients to the plants from the soil, resulted in increased growth of the plants. Application of mulch also significantly produced maximum plant height as compared to non-mulch [36]. Also, [37] found that plants cultivated on mulched soil were higher than plants from the control plot; however, treatments consisting of mulch and row covers produced significantly higher plants than treatments without row covers. A higher soil and air temperature under covers provides better conditions for plants immediately after planting and allows them to produce a higher mass of aboveground parts [38]. 
Table 3. Plant height $(\mathrm{cm})$ as affected by sowing dates, planting depth and mulching

\begin{tabular}{|l|l|l|l|}
\hline \multicolumn{3}{|c|}{ Years } & \multicolumn{2}{|c|}{$\mathbf{2 0 1 5}$} & Mean \\
\hline Sowing Date (SD) & $\mathbf{2 0 1 4}$ & 51.4 & $50.4 \mathrm{a}$ \\
\hline October 01 & 49.4 & 44.8 & $44.2 \mathrm{~b}$ \\
\hline October 15 & 43.5 & 28.0 & $29.4 \mathrm{c}$ \\
\hline October 29 & 30.8 & & 1.60 \\
\hline LSD (0.05) & & & \\
\hline Planting Depth (cm) (PD) & 41.1 & 40.8 & $41.0 \mathrm{~b}$ \\
\hline 10 & 45.4 & 45.7 & $45.5 \mathrm{a}$ \\
\hline 15 & 37.2 & 37.7 & $37.4 \mathrm{c}$ \\
\hline 20 & & & 0.80 \\
\hline LSD $(0.05)$ & & & \\
\hline Mulching (M) & 39.9 & 40.2 & $40.0 \mathrm{~b}$ \\
\hline Control & 42.6 & 42.6 & 42.6 a \\
\hline Mulching & & & $* *$ \\
\hline Significance & 41.2 & 41.4 & Ns \\
\hline Year & Sig Level & Interactions & Sig Level \\
\hline Interactions & $*$ & SD x PD x M & Ns \\
\hline SD x PD & ns & Y x SD x PD & Ns \\
\hline SD x M & ns & Y x SD x M & Ns \\
\hline PD x M & ns & Y x PD x M & Ns \\
\hline Y x SD & ns & Y x SD x PD x M & Ns \\
\hline Y x PD & ns & & \\
\hline Y x M & & & \\
\hline
\end{tabular}

Means not followed by the same letters are significantly different.

$*$, ** show probability level of 5 and $1 \%$, correspondingly. ns means non- significant

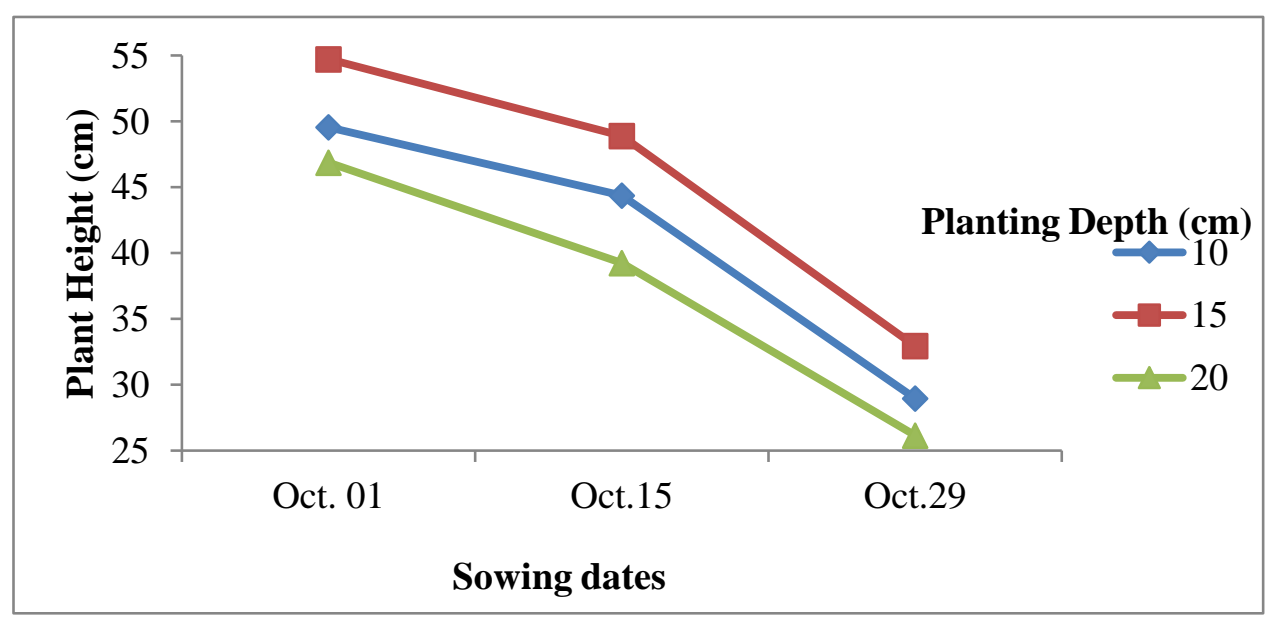

Figure 3. Plant height $(\mathrm{cm})$ of potato plant as affected by different sowing dates and

\section{planting depth}

Number of leaves plant ${ }^{-1}$

Significant variation was observed in number of leaves plant ${ }^{-1}$ with different sowing dates, planting depth and mulching (Table 4). The interaction effects of all the treatments, sowing dates were not significant except that of PD x M. The maximum number of leaves plant $^{-1}$ (33) was recorded with October 01 
sowing, while minimum (25) were noted with 29 October sowing. Regarding planting depth highest number of leaves (32) were counted in plants at $15 \mathrm{~cm}$ depth, followed by (28) at $10 \mathrm{~cm}$ depth, while deep planting at $20 \mathrm{~cm}$ produced least number of leaves plant ${ }^{-1}(25)$. Maximum number of leaves (30) was counted in plants applied with mulch, while without mulch plants produced less (27) number of leaves. The year effect was found significant. Number of leaves plant ${ }^{-1}$ was higher (29) during 2015, as compared to (28) in 2014. The PD x M interaction showed that significantly more number of leaves were produced at $15 \mathrm{~cm}$ depth both in mulch and without mulch treatment. However more leaves were recorded for mulching along with $15 \mathrm{~cm}$ planting depth (Figure 4).

Number of leaves was significantly decreased with late sowing, which might be due to chilling temperature during the growing period that caused in reduction in overall growth. The total number of leaves plant $^{-1}$ may be increases greatly by an increase in temperature, because of the combined effect of an increase in number of basal and apical lateral branches and an increase in the number of leaves on these branches [39]. There was increase in leaf number of sweet potato with increasing temperature from 20 to $28^{\circ} \mathrm{C}$. The increased in number of leaves at medium planting depth of $15 \mathrm{~cm}$ could be attributed to the depth being the optimum for plant development. The roots not being too close to the surface where the soil dry up quickly or too deep had chances of poor aeration due to too much water and soil compaction. The roots will grow in the most favorable conditions to support above ground growth. [34] obtained similar results with increased number of leaves in potato at $15 \mathrm{~cm}$ depth as compared to 10 and $20 \mathrm{~cm}$ depth. Increase in air temperature is particularly effective in increasing number of leaves, but in some cultivars high root temperature may have an additional effect, because they shift the dry matter portioning to the above ground parts resulting in better vegetative growth [39]. The increase in leaves number due to mulching can be attributed to the role of mulches in providing a favorable environment through reduce evaporation and proper moisture content for plat growth. Also mulch increased soil fertility for growth and development. Application of mulch resulted in increased number of leaves in potato as compared to un mulched plants [36], [40]. A significant variation regarding number of leaves plant ${ }^{-1}$ was observed during the year 2014 and 2015. The increased in number of leaves in 2015 could be ascribed to favorable weather condition such as optimum rain fall and temperature for potato plant growth. Water stress greatly suppresses cell expansion and cell growth due to the low turgor pressure. Soil moisture is one of the severe limitations of crop growth as it has a vital role in plant growth and development at all growth stages [41].

Table 4. Number of leaves plant ${ }^{-1}$ as affected by sowing dates, planting depth and mulching

\begin{tabular}{|l|l|l|l|}
\hline \multicolumn{2}{|c|}{ Years } & \\
\hline Sowing Date (SD) & $\mathbf{2 0 1 4}$ & $\mathbf{2 0 1 5}$ & Mean \\
\hline October 01 & 32 & 34 & $33 \mathrm{a}$ \\
\hline October 15 & 27 & 29 & $28 \mathrm{~b}$ \\
\hline October 29 & 24 & 25 & $25 \mathrm{c}$ \\
\hline LSD (0.05) & & & 0.93 \\
\hline Planting Depth (cm) (PD) & 27 & & \\
\hline 10 & & 29 & $28 \mathrm{~b}$ \\
\hline
\end{tabular}




\begin{tabular}{|l|l|l|l|}
\hline 15 & 31 & 33 & $32 \mathrm{a}$ \\
\hline 20 & 24 & 25 & $25 \mathrm{c}$ \\
\hline LSD (0.05) & & & 1.03 \\
\hline Mulching (M) & & & \\
\hline Control & 26 & 27 & 27 \\
\hline Mulching & 29 & 31 & 30 \\
\hline Significance & & & $* *$ \\
\hline Year & $28 \mathrm{~b}$ & $29 \mathrm{a}$ & $*$ \\
\hline Interactions & Sig Level & Interactions & Sig Level \\
\hline SD x PD & $\mathrm{ns}$ & SD x PD x M & Ns \\
\hline SD x M & $\mathrm{ns}$ & Y x SD x PD & $\mathrm{Ns}$ \\
\hline PD x M & $* *$ & Y x SD x M & $\mathrm{Ns}$ \\
\hline Y x SD & $\mathrm{ns}$ & Y x PD x M & $\mathrm{Ns}$ \\
\hline Y x PD & $\mathrm{ns}$ & Y x SD x PD x M & $\mathrm{Ns}$ \\
\hline Y x M & $\mathrm{ns}$ & & \\
\hline
\end{tabular}

Means not followed by the same letters are significantly different.

$*$, ** show probability level of 5 and $1 \%$, correspondingly.

ns means non-significant

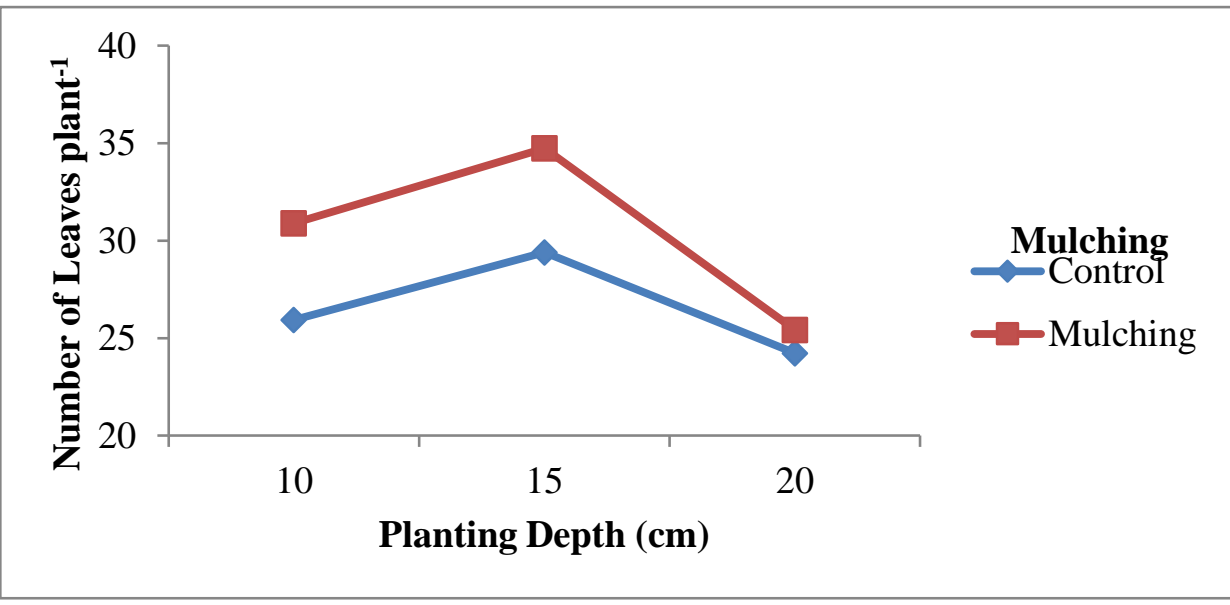

Figure 4. Number of leaves plant ${ }^{-1}$ of potato as affected by planting depth and mulching Marketable tuber yield ( $\left.\mathrm{t} \mathrm{ha}^{-1}\right)$

Marketable tuber yield was significantly affected by sowing dates, planting depth and mulching (Table 5). The interaction SD x PD and PD x M were significant. Early sowing in first week of October resulted in maximum marketable tuber yield $\left(16.2 \mathrm{t} \quad \mathrm{ha}^{-1}\right)$, which was followed by $\left(14.1 \mathrm{t} \mathrm{ha}^{-1}\right)$ in October 15 sown plants, whereas late sown plants on October 29 produced less marketable tuber yield $\left(8.9 \mathrm{t} \mathrm{ha}^{-1}\right)$. Data regarding planting depth showed that higher marketable tuber yield (13.8 $\mathrm{t} \mathrm{ha}^{-1}$ ) was obtained from plants sown at a depth of $15 \mathrm{~cm}$, while lowest marketable yield (12.4 $\left.\mathrm{t} \mathrm{ha}^{-1}\right)$ was recorded in plants planted at a depth of $20 \mathrm{~cm}$. Marketable yield was increased from (12.6 t $\left.\mathrm{ha}^{-1}\right)$ in control to (13.6 t ha- $\left.{ }^{-1}\right)$ with mulching. The year used as a source of variation also significantly affected marketable tuber yield $\mathrm{t} \mathrm{ha}^{-1}$. The maximum marketable tuber yield (13.3 $\left.\mathrm{t} \mathrm{ha}^{-1}\right)$ was produced during the year 2015 as compared to $\left(12.9 \mathrm{tha}^{-1}\right)$ in 2014. The 
(Figure 5) exhibited the SD x PD interaction, which showed that marketable tuber yield $t$ ha $^{-1}$ consistently decreased with delay in sowing from start of October to end of October at all planting depths. However sowing late in October at $20 \mathrm{~cm}$ depth resulted in maximum decreased in marketable tuber yield $\mathrm{t} \mathrm{ha}^{-1}$ with delay in sowing from October 01 to October 29 at 10 to $15 \mathrm{~cm}$ depth. The interaction between PD $\mathrm{x} M$ revealed that sowing at a depth of $15 \mathrm{~cm}$ with mulching produced more marketable tuber yield $\mathrm{t} \mathrm{ha}^{-1}$ (Figure 6).

Marketable yield increased with early sowing as compared to late sowing. Since earlier sowing produced higher percentage of larger and medium sized tubers, thus contributed to the marketable yield. As the sowing delayed, the yield was reduced. Similar results have also been reported by [42]. Other studies also confirm that potato tuber yield increased with early planting [43]. Data collected also support the results regarding tuber yield as the vegetative growth was significantly improved by planting the crop earlier and harvesting later, which increased the number of large and medium sized tubers and decreased the small sized tubers. Similarly planting depth of $15 \mathrm{~cm}$ produced maximum number of stems plant ${ }^{-1}$, number of leaves plant $^{-1}$, number of medium and large size tubers plant ${ }^{-1}$, which contributed to increase in marketable yield. [44] reported that the increase in yield of mulched plot was probably associated with the conservation of moisture and improved microclimate both beneath and above the soil surface and great weed control. Mulch provides many benefits to crop production through soil and water conservation, enhanced soil biological activity and improved chemical and physical properties of the soil [45], effectively controlled the weed growth and increased soil temperature resulting in faster emergence, early canopy development and higher tuber yield [46]. The higher yield in the second year 2015 was probably due to slightly more favorable conditions like temperature, photoperiod, soil fertility, moisture and rainfall for potato development. The high temperature during the growing season had a negative effect on yield in 2014. Water has been recognized as an important manageable input influencing potato tuber growth, development, quality and yield [47]. Water stress not only reduces total tuber yield, but also changes tuber size distribution, and tuber quality traits [48].

Table 5. Marketable yield $t$ ha $^{-1}$ as affected by sowing dates, planting depth and mulching

\begin{tabular}{|l|l|l|l|}
\hline \multicolumn{2}{|c|}{ Years } & \\
\hline Sowing Date (SD) & $\mathbf{2 0 1 4}$ & $\mathbf{2 0 1 5}$ & Mean \\
\hline October 01 & 16.0 & 16.4 & $16.2 \mathrm{a}$ \\
\hline October 15 & 13.9 & 14.3 & $14.1 \mathrm{~b}$ \\
\hline October 29 & 8.8 & 9.1 & $8.9 \mathrm{c}$ \\
\hline LSD $(0.05)$ & & & 0.20 \\
\hline Planting Depth (cm) (PD) & & & \\
\hline 10 & 12.8 & 13.2 & $13.0 \mathrm{~b}$ \\
\hline 15 & 13.6 & 14.0 & $13.8 \mathrm{a}$ \\
\hline 20 & 12.2 & 12.5 & $12.4 \mathrm{c}$ \\
\hline LSD $(0.05)$ & & & 0.18 \\
\hline Mulching (M) & & & \\
\hline Control & 12.4 & 12.8 & $12.6 \mathrm{~b}$ \\
\hline Mulching & 13.4 & 13.7 & $13.6 \mathrm{a}$ \\
\hline
\end{tabular}




\begin{tabular}{|l|l|l|l|}
\hline Significance & & & $* *$ \\
\hline Year & $12.9 \mathrm{~b}$ & $13.2 \mathrm{a}$ & $* *$ \\
\hline Interactions & Sig Level & Interactions & Sig Level \\
\hline SD x PD & $* *$ & SD x PD x M & ns \\
\hline SD x M & ns & Y x SD x PD & ns \\
\hline PD x M & $* *$ & Y x SD x M & ns \\
\hline Y x SD & ns & Y x PD x M & ns \\
\hline Y x PD & ns & Y x SD x PD x M & ns \\
\hline Y x M & ns & & \\
\hline
\end{tabular}

Means not followed by the same letters are significantly different.

*, ** show probability level of 5 and $1 \%$, correspondingly.

ns means non-significant

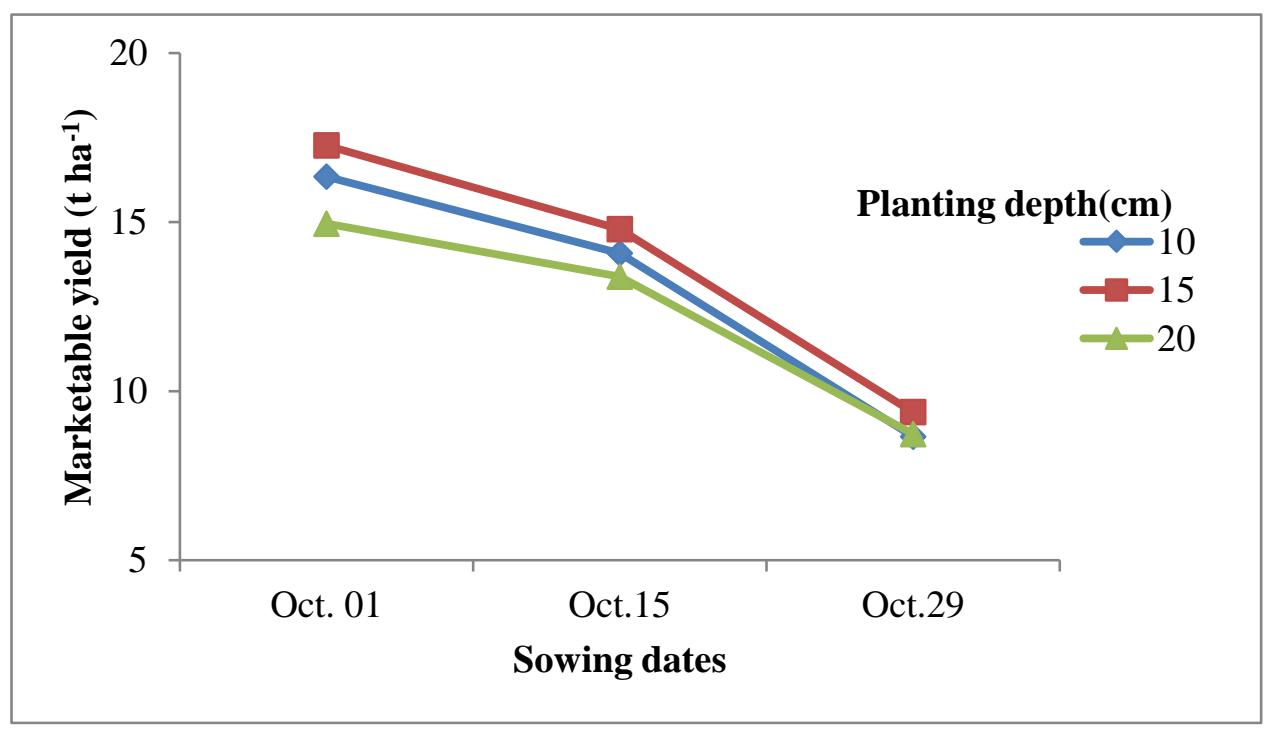

Figure 5. Marketable yield $\left(\mathrm{t} \mathrm{ha}^{-1}\right)$ of potato as affected by sowing dates and planting depth

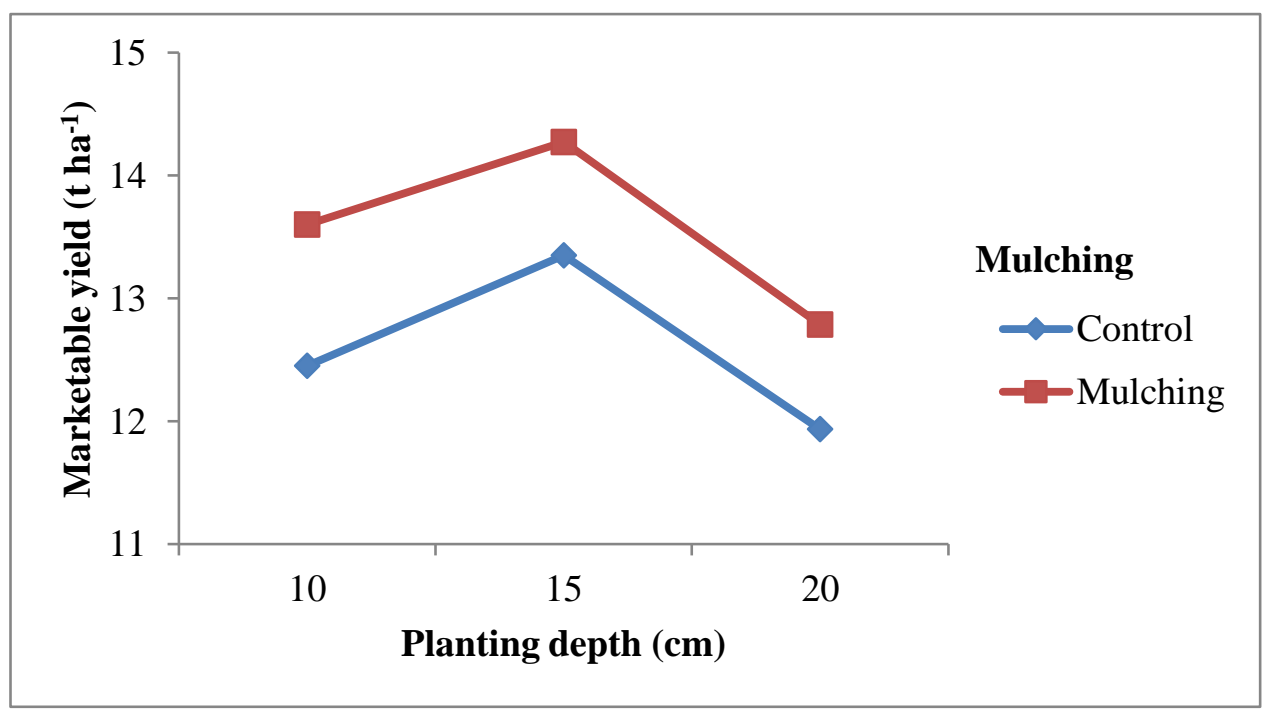

Figure 6. Marketable yield ( $\left.\mathrm{tha}^{-1}\right)$ of potato as affected by planting depth and mulching 


\section{Conclusion}

Sowing potato in the first week of October produced higher yield and yield components as compared to late sowing. Planting potato at a depth of $15 \mathrm{~cm}$ with straw mulching increased growth and yield components of autumn potato.

\section{Authors' contributions}

Conceived and designed the experiments: $G$ Ayub, Performed the experiments: M Ilyas, Analyzed the data: M. Ilyas, Contributed reagents/ materials/ analysis, tools: Department of Horticulture, Wrote the paper: M Ilyas

\section{References}

1. FAO Stat, 2010. http://faostat.fao.org.

2. Winkler E (1971). Kartoffelbau in Tirol. II. Photosynthesis vermogen und respiration yon verschiedenen kartoffelsorten. Potato Res 14: 1-18.

3. Prange RK, McRae KB, Midmore DJ \& Deng R (1990). Reduction in potato growth at high temperature: Role of photosynthesis and dark respiration. $A m$ Potato J 67: 357-369.

4. Basu PS \& Minhas JS (1991). Heat tolerance and assimilate transport in different potato genotypes. $J$ Exper Bot 43: 861-866.

5. Kleinkopf GE, Westermann DT \& Willi MJ (1988). Soil temperature effects on sugar end development. Proceedings in University of Idaho Winter Common Schools 20: 180-181.

6. Awal MA \& Khan MAH (2000). Mulch induced ecophysiological growth and yield of maize. Pak J Biol Sci 3(1): 6164.

7. Samaila AA, Amans EB \& Babaji BA (2011). Yield and fruit quality of tomato (Lycopersicon esculentum Mill) as influenced by mulching, nitrogen and irrigation interval. Inter Res J Agri Sci Soil Sci 1: 90-95.

8. Khan AR, Chandra D, Quraishi S \& Sinha RK (2000). Soil aeration under different soil surface conditions. J Agron. Crop Sci 185: 105-112.

9. Godawatte VNA, De Silva CS \& Gunawardhana MDM (2011). Effect of mulch on growth and yield of chilli (Capsicum annuum L.). pp. 8

10. Maged AEN (2006). Effect of mulch types on soil environmental conditions and their effect on the growth and yield of cucumber plants. J Applied Sci Res 2(2): 67-73.

11. Stalham MA, Fowler JH \& Pavek MJ (2001). Effect of planting depth and reridging on crop growth and tuber greening in FL 1953. In: Cambridge Univ. Potato Growers Res. Assoc. Annual Rep. Cambridge: CUPGRA, pp. 16-21.

12. Bohl WH \& Love SL (2005). Effect of planting depth and hilling practices on total, U.S. no. 1, and field greening tuber yields. Am J Potato Res 82:441-450

13. Lewis WC \& Rowberry RG (1973). Some effects of planting depth and time and height of hilling on Kennebec and Sebago potatoes. Am Potato J 50: 301310.

14. Kouwenhoven JK (1970). Yield, grading and distribution of potatoes in ridges in relation to planting depth and ridge size. Potato Res 13: 59-77.

15. Lacey J (1966). The distribution of healthy and blighted tubers in potato ridges. Eur Potato J 9: 87-96.

16. Muthoni J, Kabira J, Shimelis H and Melis R (2014). Regulation of potato tuber dormancy: A review. Aus J Crop Sci 8(5): 754 -759

17. James A \& Allemann A (2013). Literature review. Control and management of volunteer potato plants. Department of soil, crop and climate Sciences University of the Free State South Africa. 
18. Svensson B (1977). Changes in seed tubers after planting. Potato Research 20: 215-218.

19. Taiz L \& Zeiger E (2002-2010). Plant Physiology, 3rd and 5th Edition. The Benjamin Cummings Publishing Company, Redwood City - California

20. Abdulla, Alsadon A, Helmy, Wahdan M \& Wahby MF (1993).Yield and physical Properties of potato tuber as influenced by planting Depth. Colege of Agriculture, King Saud Univesiry, Riyadh, Saudi Arabia. Agric Sci 5(92): 227-235.

21. Pavek MJ \& Thornton RE (2009). Planting depth influences potato plant morphology and economic value. Amer J Potato Res 86: 56-67.

22. Firman DM, Brien PJO \& Allen EJ (1992). Predicting the emergence of potato sprouts. J Agri Sci 118: 55-61.

23. Sale PJM (1979). Growth of potatoes (Solanum tuberosum L) to the small tuber stage as related to soil temperature. Aust J Agric Res 30: 667-75.

24. Chen S, Zhang X \& Pei D (2005). Effects of corn straw mulching on soil temperature and soil evaporation of winter wheat field. Transactions of the CSAE 21(10): 171-173

25. Eruola AO, Bello NJ, Ufoegbune GC \& Makinde AA (2015). Effect of Mulching on soil temperature and moisture regime on emergence, growth and yield of white yam in a tropical wet-and-dry climate. Inter J Agri Forestry 2(1): 93-100.

26. Inyang EU (2005). An evaluation of tillage and storage systems applied by traditional root crop farmers in Cameroon. Agric Envir J 7(2): 15-22.

27. Wright J (2002). Irrigation scheduling checkbook method. Communication and educational technology services. University of Minnesota. USA.
28. Uwe S (2001). Control of potato tuber sprouting. Trends in Plant Science 6: 333-335.

29. Pavlista AD (2003). Principles of irrigation scheduling. http:www. panhandle.unl.edu/peyes

30. Ridwan I (2014). Effect of temperature and water potential on sprout vigor of potato (Solanum tuberosum L.) seed tuber. Inter J Agric System 2(2): 103111.

31. Grimstad SO \& Frimanslund E (1993). Effect of different day and night temperature regimes on greenhouse cucumber young plants production, flower bud formation and early yield. Scientia Hort 53:191-204

32. Lafta AM \& Lorenzen JH (1995). Effect of high temperature on plant growth and carbohydrate metabolism in potato. Plant Physiol 109: 637-643.

33. Ewing EE \& Struik PC (1992). Tuber formation in potato, Induction, initiation and growth. Am Soc Hortic Sci 14: 89198.

34. Tanyaradzwa ZL, Tuarira M, Moses M \& Jefta T (2015). Effects of planting depth and variety on container produced potatoes. J. Glob. Innov Agric Soc Sci 3: 17.

35. Thakur KS, Kumar D, Vikram A, Thakur A.K \& Mehta DK (2010). Effect of organic manures and bio fertilizers on growth and yield of tomato and French bean under mid hills of Himachal Pradesh. J Hill Agri 1(2): 176-178.

36. Begum M \& Saikia M (2014). Effect of irrigation and mulching on growth and yield attributes of potato. Agric Sci Digest 34(1): 76 - 78,

37. Gordon GG, Foshee III WG, Reed ST, Brown JE \& Vinson III EL (2010). The effects of colored plastic mulches and row covers on the growth and yield of okra" Horticulture Technology 1(20): 224-233 
38. Wadas W, Kosterna E \& Kurowska A (2009). Effect of perforated foil and polypropylene fibre covers on growth of early potato cultivars. Plant Soil Environ 55(1): 33-41.

39. Struik PC, Geertsema J \& Custers C (1989a). Effect of shoots, root and stolon temperature on development of potato plant (I). Potato Res 32: 133- 141.

40. Hasan D (2013). Effect of soil covers on microclimate, growth and yield of potato (Solanum tuberosum). MSc Thesis. Bangladesh Agri. Uni. Mymensingh.

41. Ahmad S, Ahmad R, Yasin M, Ashraf, Ashraf M \& Waraich E.A (2009). Sunflower (Helianthus annuus L.) response to drought stress at germination and seedling growth stages. Pak J Bot 41(2): 647-654.

42. Khan MA, Rahman H \& Yaqub CM (1990). Effect of different harvesting dates on the performance of spring and autumn produced cardinal potatoes. $P a k$ J Agri Res 11 (2):93.

43. Workman M \& Harrison MD (1982). Influence of harvest date on yield, earlyblight tuber infection and chipping characteristics of potatoes grown with sprinkler irrigating. General Series, Experiment Station, Colorado State University, No. 989. pp. 14 (Potato abstracts) 35(4): 3357.

44. Mondani F, Golzardi F, Ahmadvand G, Ghorbani R \& Moradi R (2011). Influence of weed competition on potato growth, production and radiation use efficiency. Not Sci Biol 3(3): 42-52

45. Kumar SD \& Lal BR (2012). Effect of mulching on crop production under rainfed condition. A review. Int J Res Chem Enviro 2(2): 8-20.

46. Bakht T \& Khan IA (2014). Weed control in tomato through mulching and herbicides. Pak J Bot 46(1): 289-292.

47. Belanger $\mathrm{C}$, Walsh JR, Richard JF, Milburn PH \& Zaidi N (2000). Yield response of two potato cultivars to supplemental irrigation and nitrogen fertilization in New Brunswick. Amer $J$ Potato Res 77: 11-21.

48. Kumar D, Ezekiel R \& Khurana SMP (2003). Effects of location, season and cultivar on the processing quality of potatoes. J Indian Potato Assoc 30: 247-251. 